\title{
THE PROGRESSIVE PALATALIZATION OF SLAVIC
}

\author{
FREDERIK KORTLANDT
}

Contemporary mainstream linguistios has a strong theoretical bias. This has often led to a negligent attitude toward the data, especially among linguists of a generative persuasion ${ }^{1}$. Adequate knowledge of the material, though a prerequisite for any useful scholarly activity, is no guarantee of a valid analysis, however. In the following I intend to show how one or two false theoretical assumptions can lead astray a scholar who is known for his insistence on the perusal of an accurate and comprehensive body of data.

1. As far as I can see, the final statement on the conditions and chronology of the Slavic progressive palatalization has been reached by A. Vaillant (1950: $53-55$ ). Though the problem has rem ained popular among historical linguists and has even been the subject of a number of monographs ${ }^{2}$, later efforts have neither disproved Vaillant's view nor yielded a better alternative.

Vaillant's position can be summarized as follows: $*_{k}, *_{g}, *_{\mathrm{x}}$ became fronted after $*_{i}, *_{i}, *_{i n}$ unless they were followed by a consonant or by one of the high rounded back vowels ${ }^{*}{ }_{u},{ }^{*}{ }^{3}$. This assimilation did not take place after the diphthongs * ${ }_{a i}$ and $*_{e i}$ because these did not end in $*_{i}$ any longer. There is no reason to separate the progressive palatalization chronologically from the second regressive palatalization, which yielded the same reflexes in all Slavic languages. The locative forms otbci, otbcixz 'father(s)' adopted the endings of the soft inflexion; the original endings were preserved in lbzě 'permitted', sicěxz 'such', cf. rocěte 'say' (pl)'.

2. This view has a number of consequences for the relative chronology of sound laws:

1 Cf. Kortlandt 1983b.

2 Jeżowa 1968, Channon 1972, Lunt 1981.

${ }^{3}$ The lattor condition was first proposed by A. Belić (1921 : 25 - 26). 
2.1. If the progressive palatalization was blocked by a following rounded *u or $* \bar{u}$, this implies that the delabialization of the latter was posterior to the palatalization.

2.2. If the diphthongs *ai and * $i$ did not end in *i any longer, the progressive palatalization was apparently posterior to their monophthongization.

2.3. If * $i$ from *ei did not cause palatalization of a following velar, the merger of the diphthong with ealier $* \tilde{i}$ was posterior to the palatalization.

2.4. The latter two statements suggest that *ei yielded close $*_{\bar{e}}$, which was subsequently raised to $*^{*} \bar{i}$.

2.5. Since $\check{e}$ and $a$ remained distinct after the newly palatalized consonants, the progressive palatalization was posterior to the retraction of $\check{e}$ to $a$ after $\dot{j}, \breve{c}, \check{z}, \check{s}$.

2.6. Since $* i$ from $* u$ after $* j$ did not cause palatalization of a following velar, e.g. igo 'yoke', its merger with earlier * $i$ was posterior to the palatalization.

2.7. The latter two statements imply that the vowel adjustment after $* j$ caused the merger of $*_{\tilde{e}}$ with $* \tilde{a}$, but not the merger of $* u$ with $* i$.

2.8. The first and the last statement suggest that * $u$ was fronted to $* \ddot{u}$ by a preceding $* j$ before the palatalization, and delabialized to $* i$ at a later stage.

2.9. The latter two statements suggest that the delabialization was early in the case of the low vowels and late in the case of the high rowels ${ }^{4}$.

3. In his recent study of the progressive palatalization (1981), Horace Lunt adopts Mareš's view (1969: 13) that ${ }^{0} o,{ }^{*} \bar{o}, * u, * \bar{u}$ were delabialized to $* a, * \bar{a}, * y, * \bar{y}$ in early Slavic, which became distinct from Baltic as a result of this development, and that the language remained without rounded vowels until shortly before the oldest texts (Lunt 1981: 15 and n. 17). His offhand. rejection of alternative views as "oubmoded", though it is in line with a popular device of argumentation in generative linguistics, does not contribute to a scholarly discussion. It is not only highly improbable that a system without rounded vowels would have survived over 2000 years of linguistic evolution, but there is actually no evidence that it ever existed in the Slavic area.

4 Cf. Kortlandt $1979: 265-268$. 
4. Lunt claims that "internal reconstruction alone suffices to establish a stage where every desinence in the OCS twofold declension begins with ${ }^{*} a$ or ${ }^{*} \vec{a}$. A number of variant proposals may be made [...], but nothing changes the major fact: all desinences begin with a low back vowel" (16). This formulation exemplifies another basic device of generative argumentation, viz. the presentation of underlying forms, which are established on the basis of general principles, as major facts of a language. Yet there is no evidence that Lunt's underlying paradigms ever existed as a synchronous system at any stage in the prehistory of Slavic. 5. According to the available evidence, the following endings of the $o$ - and $\bar{a}$-stem paradigms began with a high rounded back vowel at the time of the progressive palatalization:

5.1. acc. sg. masc. and gen. pl. $-z<{ }^{*}-u<*^{*}-o m$. As I have pointed out elsewhere $(1978,1983 \mathrm{c})$, the raising of ${ }^{\circ} o$ to $* u$ in this ending must be dated to the Balto-Slavic period.

5.2. acc. pl. mase. fem. $-y<{ }^{*}-u N s<{ }^{*}-o n s,{ }^{*}-\bar{a} n s$. The raising in this ending was anterior to the vowel adjustment, which was in its turn anterior to the palatalization ${ }^{5}$.

5.3. inst. pl. masc. neut. $-y<{ }^{*}-\bar{u} s<*-\bar{o} i s$. Lunt's reconstruction **k-as ("its connection with hypothetical IE *-ois is unclear", 17) is entirely gratuitous. The same holds for his reconstruction of gen. pl. **-as.

6. In addition to these endings, Lunt's reconstruction of the following is only partly in accordance with the available eridence: nom. acc. sg. neut., gen. sg. fem., inst. sg., gen. du.. nom. pl. mase. fem., dat. pl., inst. pl. fem. Since I have discussed most of these endings elsewhere $(1975,1983 \mathrm{c})$, therc is no reason to go into the matter here. Lunt disregards the prosodic evidence, which is crucial for an understanding of the morphophonemic processes. He proposes that the pronominal nom. pl. masc. ending $*_{\text {-oi adopted }} *_{-s}$ from the other stem types and that the resulting ending *-ois developed phonetically into $-i$. The same proposal was put forward several times in the earlier literature (e.g. Ebeling $1963: 32$, Mareš $1963: 55)$. It is unclear how this can have escaped Lunt's attention ${ }^{6}$.

5 Cf. Kortlandt $1979: 265$.

- Lunt's discussion of Birnbaum's view in terms of "prejudice" and "error" (n, 21) is another exmmple of the generntive style, and so is his 
7. The absence of the progressive palatalization after the diphthongs *ai and * $e i$ forces Lunt to assume that the latter were lowered to *ae and *ee and to specify the exclusion of the diphthongs in his formulation of the palatalization rule (19f). The only advantage of this ad hoc solution is that it saves his "underlying" representation /ai/./ei/. As soon as we drop the a priori assumption that the diphthongs were preserved up to the time of the progressive palatalization, the natural solution commonds itself: the palatalization was posterior to the monophthongization of the diphthongs, which yielded long monophthongs of the limbre *ä, *e. 8. Lunt adduces igo < "yugom "yoke" in favor of the view that the fronting of *u was posterior to the progressive palatalization (20). This reasoning is based on the a priori assumption that the delabialization of " $u$ was an carly Slavic development. The assumption is false, as was pointed out above. Since the progressive palatalization was apparently blocked by a following high rounded back vowel, the delabialization was posterior to tho palet ilization. and Lunt's argumentation breaks down.

9. Lunt claims that ${ }^{*} a$ and $* \bar{u}$ were raised to $* y$ and $* \bar{y}$ before word-final $*_{-s}$ in certain desinences (nom. sg., inst. pl., ace. pl., nom. pl. of the masc. $o$-stems). Though he states that there is "no clear evidence for dating this process", he submits that "in any case it happened well after [the progressive palatalization] had been completed as a phonotic process" (22). This surely is a remarkable piece of argumentation.

Since I have pointed out elsewhere (1983c: 180-182) that $*$-os and $*_{-o s}$ were not subject to raising, I shall not return to the question here. The raising of $*_{-o N s}$ and $*_{-o i s}$ to ${ }^{*}-u N s$ and *-uis can be dated before the delabialization of *o, which was anterior to the vowel adjustment, which in its tu^l proeeded the palatalization?

10. Lunt lumps together the fronting of *u, * $\bar{u}, * a$ to $* i, * \bar{v}, * e$ and the backing of $* \bar{e}$ to $* \bar{a}$ after $j, \tilde{c}, \tilde{z}, s$ as "the adjustment of vowels after palatals" (23) and claims that this process was posterior to the progressive palatalization. This chronology accounts for

dismissal of Shevelov's opinion as "blatantly faulty" (n. 23). It would be interesting to investigate the sociological factors which have induced the substitution of strong language for reasoned argumentation.

$?$ Cf. Kortlandt 1979 : 265. 
the regular soft paradigm endings of the locative forms otbci, otbcixz 'father(s)', but not for petrified, pronominal, and verbal forms such as lazě 'permitted', sicěxz 'such', rocête 'say' (pl)'. It forces Lunt to look for ad hoc explanations of the latter instances. Thus, he posits a form "rbcite" for which there is simply no evidence and which was supposedly ousted in the entire Slavic area in prehistoric times.

If we take the evidence at face value, it is clear from the phonemic contrast between $\alpha$ and $\check{e}$ after the soft consonants which resulted from the progressive palatalization that the backing of $* \bar{e}$ to $* \vec{a}$ was anterior to the rise of these consonants. Since the backing of $* \bar{e}$ to $* \bar{a}$ was posterior to the first regressive palatalization, it follows that Lunt's chronology cannot be maintaincd.

Lunt is unable to offer an explanation for the self-contradictory nature of his vowel adjustment rule, as he admits himself (n. 60). In my view, the retraction of $* \bar{e}$ to $* \bar{a}$ was conditioned by the rise of new long front vowels from the monophthongization of the diphthongs $* a i$ and $* i{ }^{s}$. Sinco this development affected the long vowel system only, short ${ }^{*} e$ was not retracted to $* a$.

11. The hypothesis that the progressive palatalization was carly forces Lunt to reformulate it as a subphonemic development: 'In distinctive terms, the [resulting] $k$ ' apparently remains a variant of $/ \mathrm{k} /$ even after [the first regressive palatalization] has operated. Phonologization comes about when *kja becomes $* \dot{c} \vec{a}$ and thus opposed to *kca, but this still leaves Gen. "atik' $\bar{a}$ (vs. "atic $\bar{c} \vec{a})$ with a $k^{\prime}$ which is a variant of underlying $/ \mathrm{k} / "(27 \mathrm{f})$. This renders Lunt's chronology practically meaningless. He is "tempted, however, to see grounds for phonemic $k^{\prime} / g^{\prime}$ earlier. Perhaps affective factors may have helped" (n. 83). The choice is between resisting the temptation and giving up principled methodology.

According to the standard view, the phonologization of the new palatals was achieved when the conditioning $* i, * i \tilde{i}, * i N$ merged with the reflexes of $* u,{ }^{*} e i, * e N$ in the appropriate environments. This happened as a result of the unrounding, raising and lowering processes which marked the period after the palatalizations ${ }^{9}$.

12. 'The Russian idiom ni zgi ne vidno 'it is pitch-dark' and its

\& Cf. Kortlandt $1979: 266$.

9 Cf. Kortlandt 1979 : 268 f. 
dialectal variant stegi ne vidat' (Vasmer 1953: 449) contain the gen. sg. form *stbgy of the word stezjá 'path', Old Polish sicdza, Slovene stezà. Lunt affirms that "the old genitive should be "st (31). This should be the case if Lunt's theory were correct. It is not the case, however. The form shows that the high rounded back vowel of the gen. sg. ending blocked the progressive palatalization, and thereby disproves Lunt's theory.

13. The form lozě 'permitted', like trěbě 'necessary' and godě 'pleasing', is a petrified locative. It shows that the regular soft paradigm ending $-i$ is analogical in the case of nouns which were subject to the progressive palatalization. Lunt submits that

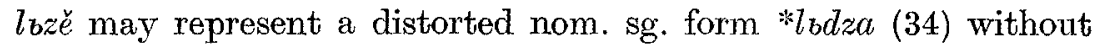
adducing any evidence for his proposal.

14. The incorrectness of Lunt's theory is confirmed by the pronominal inflexion of $v b s b$ 'all' and sicb 'such', e.g. inst. sg. ma se. vbsěmb, sicermb<*-oi-. The former word represents early Slavic *vix-, as is clear from the West Slavic reflex $v s^{\circ}$ and from $v x$ - in the Old Russian dialect of Novgorod. The latter reflex is phonetically regular in the acc. sg. masc. and acc. pl. masc. fem. forms (cf. Belić 1921:28). The word cannot be compared with sb "this", which combines a hard stem (which is evident from the West Slavic material) with soft paradigm endings. In view of this combination, Van Wijk calls the hypothesis that $v b s b$ "seine - $i$-Kasus unter dem Einfluss der harten Stämme (těmb usw.) aufgegeben habe" unacceptable (1931:68). Lunt asks perplexedly: "Why unacceptable? On the contrary, pronouns are far more likely to develop peculiar innovations along with haphazard rearrangements of old materials" (36). The methodological principle that anything goes surely puts an end to all scholarly discussion.

As Van Wijk points out, "in der nominalen Flexion sind die Kasus mit ě-Vokalismus weniger zahlreich als in der pronominalen" and therefore more easily affected by analogical replacement: the relevant cases are loc. sg. (all genders) and pl. (masc. neut.), dat. sg. (fem. only), and nom. ace. du. (fem. neut.) in the nominal paradigms, and inst. sg. (masc. neut.), all oblique pl. and du. cases except gen. loc. du. (all genders), and nom. acc. du. (fem. neut.) in the pronoun. The pronoun $s b$ represents a conflation of the PIE. particle * $k i$ 'here' with the anaphoric pronoun * $e$, * $i$-, as I have pointed out elsewhere (1983a: 313$)$. There is no reason 
to adopt Lunt's desperately agnostic attitude: "I merely contend that the explanation for all the variants is to be found (1) in the hypothesis that [the progressive palatalization] applied only to $k$ and $g$ and not to whatever fricative was developing from $*_{s}$ in the earliest Slavic, and (2) in the hypothesis that the early Slavic pronouns represented in OCS by $s b$ and vbsb had idiosyncratic declensions that we cannot recover" (37), and "I venture to suggest that sicb had a special, idiosyncratic history" (n. 124). Though either (1) or (2) suffices to exclude vbsb from consideration, Lunt introduces a third safety-valve by questioning the velar origin of the fricative, in spite of the available evidence. Note that the entire chain of reasoning rests upon a single false assumption, which is a consequence of his unwillingness to recognize the analogical origin of the soft paradigm endings in the locative forms otbci, otbcixz 'father(s)'.

15. To summarize, Lunt's chronology cannot be maintained. It is based on a few a priori assumptions which cannot be substantiated and which force him to posit an arbitrary phonetic development of the diphthongs and an arbitrary morphological replacement in the imperative, to reformulate the progressive palatalization as a subphonemic development, to dismiss the counter-evidence of petrified forms by questioning the material without offering a solution, and to exclude pronominal forms from consideration because they may have been subject to unknown developments. Here Lunt's own words come to mind: "Troublesome items which interfere with the neat patterns one wishes to find can be minimized, but they should never be omitted" (9).

At an earlier stage of his career lunt "was ready to believe that the descriptive priority of [the progressive palatalization] in my own analyses was an artifact of the method" (14). The question remains pertinent. It can only be answered by reconsidering fact and fiction against the background of previous work in the field. This means that we must take earlier scholarship seriously. The issues have been around for a long time, and so have most of the data ${ }^{10}$. The cavalier treatment of other people's

10 An exception must be made for the forms which show vbx- in the Novgorod birch-bark documents that have been unearthed in recent decados. 
views which is characteristic of much recent work does not contribute to a clarification of substantial problems. We must hope that the renewed interest of the post-generative generation in a factual analysis of the data will have a salutary effect on the ass essment of earlier scholarship.

\author{
FREDERIK KORTLANDT \\ University of Leiden \\ Faculty of Letters \\ Cobetstraat 24 \\ $2313 K C$ LEIDEN \\ HOLLAND
}

\title{
REFERENCES
}

Belić, A.

1921 "Najmladja (treća) promena zadnjenepčanih suglasnika $k, g$ i $h$ u praslovenskom jeziku", Južnoslovenski Filolog $2: 18$ - 39.

Channon, R.

1972 On the place of the progressive palatalization of velars in the relative chronology of Slavic (The Hague: Mouton).

Ebeling, C. I.

1963 "Questions of relative chronology in Common Slavic and Russian phonology", Dutch contributions to the fifth international congress of Slavicists (The Hague: Mouton), 27 - 42.

Jeżowa, M.

$1968 Z$ problemów tak zwanej trzeciej palatalizacji tylnojęzylcowych w języlcach stowianslich (Wrockaw: Wydawnictwo PAN).

Kortlandi, F.

1975 Slavic accentuation: $A$ study in relative chronology (Lisse: Peter de Ridder).

1978 "On the history of the genitive plural in Slavic, Baltic, Germanic, and Indo-European", Lingua 45:281 - 300 .

1979 "On the history of the Slavic nasal vowels", Indogermanische Forschungen $84: 259-272$.

1983a "Demonstrative pronouns in Balto-Slavic, Armenian, and Tocharian", Dutch contributions to the ninth international congress of Slavists: Linguistics (Amsterdam: Rodopi), 311 - 322.

$1983 b$ "Linguistic theory, universals, and Slavic accentuation", Fabia Linguistica Historica $4: 27-43$.

$1983 c$ "On final syllables in Slavic", Journal of Indo-European Studies $11: 167 \cdot 185$. 
Lunt, H. G.

1981 The progressive palatalization of Common Slavic (Skopje: Macedonian Academy of Sciences and Arts).

Mareš, F. V.

1963 Vznik a raný vývoj slovanské dekli ce, Československé prednášky pro V. mezinárodní sjezd slavisti $v$ Sofii (Praha: Nakladatelství Československé Akademie Věd), 51 - 69.

1969 Diachronische Phonologie des Ur-und Frühslavischen (München: Otto Sagner).

Vaillant, A.

1950 Grammaire comparée des langues slaves I: Phonétique (Lyon: Éd. IAC).

Vasmer, M.

1953 Russisches etymologisches Wörterbuch I (Heidelberg: Carl Winter). Van Wijk, N.

1931 Geschichte der alttirchenstavischen Sprache I: Laut- und Formenlehre (Berlin: Walter de Gruyter). 